Fernandez, Camargo, \& Nascimento. Technologies and environmental education: A beneficial relationship.

\title{
Technologies and environmental education: A beneficial relationship
}

Antonio Hernández Fernández *

antonio.hernandez@ujaen.es

Claudia De Barros Camargo

claudiabarros@correo.ugr.es

Maria Selma Lima Do Nascimento

msl00027@red.ujaen.es

*Corresponding Author: antonio.hernandez@ujaen.es

Received : 08.08.2019

Accepted : 09.21.2019

How to cite this paper: Fernandez, A. H., Camargo, C. B., \& Nascimento, M. S. L. (2019). Technologies and environmental education: A beneficial relationship. Research in Social Sciences and Technology, 4(2), 13-30.

\section{Abstract}

Educational technologies have an important role in education today. They represent a relevant resource in the process between theorizing and educational practices, and they are essential in the awareness process for sustainability. Thus, technological education appears as a facilitator in this process, especially with students, parents, and everyone around us, as being supported by tech resources to produce an efficient effect. This study was performed at Escola Municipal de Ensino Fundamental in Alagoinha-Paraíba, Brazil, between January and February, 2019; the research question is: Are teachers using and recognizing technology as a partner in the environmental awareness process? The main objective is to analyze the usage of tech in the process for environmental awareness by teachers. The specific objectives are: to check the usage of technological education in the environmental awareness process, to comprehend the challenges faced by the teachers in the process of technological usage on the scope of environmental education, to identify the activities developed by the teachers involving tech and environmental education, and to perceive the educational practices. A total of 22 teachers responded to the questions. Data collection was made on a Likert scale using the qualitative method and descriptive research. The Likert scale was validated on its construction with analysis factor. Therefore, it was found that the teachers use the tech resources in their classes, through the environmental awareness, besides defending the educational projects and realizing interdisciplinary works about environmental education for environmental conservation.

Keywords: Environmental Education, Educational Technologies, Environmental Awareness

\section{Introduction}

Environmental education arose from the eminent need for environmental preservation, and, given this concern to be careful and zealous for nature and everything that belongs to it, 
Fernandez, Camargo, \& Nascimento. Technologies and environmental education: A beneficial relationship.

humans as integral parts of nature also began to organize some strategies for society to learn how to value the importance of this theme. According to Maciel et al. (2019), contact with nature is very important for individuals because they learn a lot about existing values in society, always focusing on conservation and sustainability care.

The present study has the general objective of analyzing the use of technologies in the process of environmental awareness by the teachers of the Municipal School of Primary Education in Alagoinha, Paraíba, Brazil, with these specific objectives: to verify the usage of educational technologies in the process of environmental awareness, to understand the challenges faced by teachers in the process of using technology in environmental education, and to identify the activities developed by teachers involving technology and environmental education (Boutelier, 2019).

According to the United Nations Educational, Scientific and Cultural Organization (UNESCO, 2005), environmental education has great relevance in the process of environmental awareness, and a school is an ideal place for this achievement in defense of nature. Technological education appears as a facilitator in this process, especially with students, parents, and everyone around us, as being supported by the tech resources to produce an efficient effect.

\section{Review of Literature}

\section{Environmental education}

The protection of nature is the responsibility of all, since it is a collective good, as long as people feel concerned for preservation. In Brazil, conservation is a right and a duty of all citizens. Thus, according to the Federal Constitution of Brazil (1988), in accordance with article 225, everyone has the right to a balanced environment, common to all people, and the public and the community are responsible for its care and defense now and for future generations. It is the duty of education, through public policies, to provide students of all ages with the knowledge and understanding of natural phenomena. That is, this action allows an intellectual construction of environmental protection, where the population maintains the construction of sustainability. In 1987, UNESCO presented a document attributing a link between underdeveloped or developing countries and the degradation of nature, because it is also related to the need for survival. In this regard, several subsequent problems arise, such as soil degradation, land becoming barren, deforestation, and reduction of agricultural production; it is important to start early the process of awareness in every part of society.

\section{The concept of environmental education}

Understanding the concept of environmental education is important because it is not easy to define it, for it is a multidisciplinary issue and depends on diverse contexts existing in society, history, economics, law, geography, and tourism, important details fundamental to this process. 
Fernandez, Camargo, \& Nascimento. Technologies and environmental education: A beneficial relationship.

Therefore, we find it expressed in the law that establishes the National Environmental Education Policy, as evident in Article 1 of Law No. 9.795 / 99 (Brasil, 1999):

Environmental education is understood as the processes through which the individual and the community construct social values, knowledge, skills, attitudes, and competences aimed at the conservation of the environment, as well as the common use of the people, essential to the healthy quality of life and its sustainability (Brasil, 1999).

The principles of education are also present in Article 1 of Law No. 9.795 / 99 (Brasil, 1999), especially when there is mention of the citizenship principle, the student's development in maintaining a good quality of life and propagating good attitudes to enforce quality environmental education. Another concept of environmental education can be found in the Dictionary of Meanings (2019), as it is very significant to understand that environmental education is a teaching area aimed at raising individuals' awareness of environmental problems and how to help combat them by conserving natural reserves and not polluting the environment. Environmental education aims at preserving the precious resource that is nature and everything that surrounds it. It aims to seek the various solutions from the point of view of social, ethical, economic, ecological, and environmental aspects. This is a task that awakens in society the concern about what causes damage to nature: deforestation, soil degradation, air and water pollution, and garbage. Today, these concerns occur in several nations around the world, for it is a collective problem.

\section{Environmental education and technology education}

Society is dependent upon technology. The speed at which information reaches its destination is impressive, and in record time it transcends information and changes in all sectors of the current society, above all reflecting on the health, education, politics, and practices of everyone involved in this reality.

There is no doubt that technology brings many transformations to education, and with this there is great possibility for the student and teacher to expand their knowledge, helping in classroom discussions and encouraging interest. For Cabero and Cejudo (2006), of the great revolutions in human communication, undoubtedly technology is the most current in our time. Defining technology goes beyond a simple concept; indeed, it is saying something very innovative, current, and necessary in contemporary society. Hernández Fernández and De Barros (2016) suggest that ICTs can help in various aspects of society: improving learning, innovating practices, and changing organizations. ICTs are dynamic, and currently we find three forms of application: ICT (Information and Communication Technology), TAC (Technology for Learning and Knowledge), and TEP (Technology for Empowerment and Participation). The use of technologies can favor a quality education when associated with Inclusive Education, for it is able to eliminate barriers, and for some it is the only access to the educational and cultural world (Hernández Fernández \& De Barros, 2016; Lafer \& Tarman, 2019; Valiandes \& Tarman, 2011). According to these authors, the policies of incorporation of the technologies in the schools favor learning; however, it is also necessary to reflect about results and whether the 
Fernandez, Camargo, \& Nascimento. Technologies and environmental education: A beneficial relationship.

teachers have competence for its usage. The availability of technology should be a reason for inclusion, although on some occasions there is what is known as "digital exclusion." Thus, at the same time, we cannot fail to emphasize the importance of technologies in schools, to be used in an educational and methodological way (Hernández Fernández \& De Barros, 2016, p. 238).

In an inclusive school, digital inclusion must be present, understood as the attempt to balance the different digital gaps that appear in the social field, not only those related to the diverse socioeconomic and cultural conditions of students, but also those related to students who have developed different strategies in their approach to technologies (Hernández Fernández \& De Barros, 2016, p. 238). The school must maintain the character of inclusion, adjust to the limitations of the students, and use material and human resources to pursue this goal. Therefore, teacher training is essential in the process of building Information and Communication Technologies (ICTs) in inclusive education. Today, teacher training is a primordial process that does not end in training courses but must always be focused on social practice, as reflected by Pimenta (1995). In this environment, teachers must acquire knowledge and transform it into great educational practices, always reflecting and doing new actions. For Passarelli (1993), there are three main theories that govern the use of computers in basic education: System Theory, Behavioral Theory, and Cognitive Theory. The instrumental form of the computer is based on Behavioral Theory, System Theory makes relation with all structure and organization, and the Cognitive approach has relation with the information where the human intelligence is actuated of diverse forms to codify, store, and compare information.

In everything expressed previously, there are several reasons for the use of technology in education, because when used in a cognitive approach, it allows the student to encode, acquire knowledge, express opinions, and transform reality. The use of technology reinforces a paradigm that allows an interaction between the information and the opinion of the acquired knowledge. According to Belloni (2001), this is the reality of interaction between technology and education. Education is always a communication process, and technology gives the student a new worldview; the school is a perfect space to accumulate new knowledge and change reality, so "tech" is very conducive to education. The school has a great challenge to work with such important themes, so it is good to know how teachers experience this theme at school.

\section{Historical assumption and environmental awareness}

A document that indicates all the above discussion about environmental education, the "Belgrade Charter," organized at the Belgrade Conference, is a great historical reference for the principles that guide and regulate the environment and school subjects. In the $21^{\text {st }}$ century, due to problems of environmental contamination and urban population growth, studies and concern for nature have begun to be of considerable magnitude. The European naturalists were the first investigators of this phenomenon. According to Dias (2001), British researcher Patrick Geddes aroused interest in this subject. He was known as the Father of Environmental Education for his reflection on the post-Industrial Revolution process, where impacts on nature and the threat to the quality of life for all became urgent. Dias (2004) further states that in 
Fernandez, Camargo, \& Nascimento. Technologies and environmental education: A beneficial relationship.

1952, after numerous deaths in London as a result of air pollution, there was a collective mobilization in defense of the environment and a dignified quality of life for the people of the planet. The effects of this event alerted other countries, with the emergence of "environmentalism" in the United States in 1960.

After this, international concern began on this subject from the International Union for the Conservation of Nature (IUCN), which occurred in 1971, and the concept of environmental education was limited to environmental preservation related to animal life (Dias, 2004). According to Sato (2004), it was in 1972, through an international conference, that significant advances were made when the United Nations (UN) integrated humans as that primordial being in the process of raising awareness about the importance of nature for life. In 1992, the United Nations Conference on Environment and Development (UNCED), also known as Rio-92, was held in Rio de Janeiro, Brazil, with the goal of promoting discussions on environmental issues. Scientists debated the social dimension of the environmental problem. Humans were previously considered the most important being of this awareness, but now the vision of this conception is broader and goes back to humans as "environmental partners" in society; all changes have the objective of solving or mitigating the problem (Mendonça, 2002). Much change was added, all approved by a large majority of speakers, including NGOs, civil society, researchers, and influential people in the media and in society, and all defended the principles of respect and care for the environment. Furthermore, the value of education in the process of awareness, the responsibility of society, social and economic justice, respect, ecological aspects, and quality of life for everyone on the planet were discussed. With this, they made a document called "Agenda 21," dealing with the primordial agreement between nature and society (Mendonça, 2002). Parallel to Rio-92 was the Global Forum-92 and a document named "Earth Charter," in which environmental education is defined as a dynamic process of conscious, individual, and especially social transformation maintaining great emphasis on sustainability.

According to Mendonça (2002), after these events, environmental education became part of the school context, through the perspective of globalization of education and the relevance as a guiding role for a sustainability awareness. Therefore, the UN decreed a decade of education for sustainability, 2005-2014. Dias (2004) states that on April 27, 1999, Environmental Education became a law, part of the National Policy for Environmental Education (Act 9795/99), recommending in Article 2 that: "Environmental Education is an essential and permanent component of national education, and must be present, in an articulated way, at all levels and modalities of the educational process, both formal and non-formal."

\section{Practices in environmental education}

The environmental proposal in basic education rescues some paradigms, values, and new pedagogical practices that will transform conscious subjects and citizens with an important role of changing a reality. According to the Environmental Education Law No. 9795 of 1999, environmental education must develop in the primary, secondary, and higher teaching-learning processes within the curriculum, involving all segments through education, from basic education to higher and vocational education. The law ensures that it must intervene in 
Fernandez, Camargo, \& Nascimento. Technologies and environmental education: A beneficial relationship.

education through activities, in schools, through awareness and changes to an ecologically transformative thinking. It is not necessarily a subject, but it easily facilitates the interaction of the curriculum in schools adapting to all areas of knowledge. According to Alkimin et al. (2019), in order to realize a work of environmental awareness in the school space, it is pertinent to go through teacher education, be it initial or continued, as these spaces are rich in the art of researching, investigating, and using creativity in the teaching process.

According to Leff (2002), the knowledge acquired by environmental education is very broad and involves several areas of knowledge based on values and attitudes linked to sustainability for a current and conscious education; it can be worked in the school in an interdisciplinary way, helping much in the process of valorizing the environment.

For this, Brazil (2012) argues that DCNEA collaborates through science and technology to raise awareness about sustainability. For this, historical, socio-environmental, political, and economic knowledge in defense of this process are pertinent. One of the goals of EA in the DCNEA article 13, subsection $\mathrm{VI}$, ensures that science and technology as a support to strengthen themes in all sectors of the educational curriculum. In title III, referring to curricular organization, in article 17, item I, letter a, it suggests the integration of several sectors of society, together with political, geographic, environmental, psychological, and relations between science, culture, and technology. Technology is a splendid resource today for the process of knowledge and change of thought in relation to nature, as well as communication through technological resources in learning.

\section{Methods}

\section{Development}

This research is quantitative, because according to Hernández Fernández and De Barros (2018), an investigation has as its primary objective to study the properties and quantitative phenomena and also the relationships that provide the review of existing theories.

The instrument used for data collection was a Likert scale, which consists of a series of items that explore the research object. For each item, we have a scale of 1 to 5, from much in disagreement to very much in agreement. The Likert scale was constructed with an operation table using the specific objectives of the research.

The application of the Likert scale had as a general objective to analyze the use of the technologies in the process of environmental awareness by the teachers of the Municipal School, and the following specific objectives: to verify the use of educational technologies in the process of educative awareness, to understand the challenges faced by teachers in the process of using technology in environmental education, to identify the activities developed by teachers involving technology and environmental education, and to realize the educational practices of teachers. The type of search is within the descriptive scope level. According to Gil (2008, p. 28), the descriptive research seeks to describe characteristics of a given population, 
Fernandez, Camargo, \& Nascimento. Technologies and environmental education: A beneficial relationship.

phenomenon, or the establishment of relations between variables. The population studied comprises all the teachers of the municipal school studied, totaling 22 teachers who participated in the research of their own free will, signing a Free and Informed Consent Form according to Resolution 196/96 of the Ministry of Health on research involving human beings, comprising the teachers who teach the children to the 5th year, besides those who work in the rooms of Specialized Educational Assistance (AEE) of the referred school. Research design, in the words of Pérez Ferra (2009), the method is the procedure to reach the objectives and the methodology constitutes the study of the method. For him, one takes as reference the classification provided by Bisquerra (1989), which focuses on how the research methods can be oriented, either to obtain basic knowledge or to obtain knowledge applied to decision making and the actions for the exchange of knowledge. This research is exploratory and descriptive in nature and will adopt a quantitative methodology. For the accomplishment of the research, we used a Likert scale as the instrument of data collection.

\section{Population and sample}

The population to be investigated is formed by teachers of the Municipal School in focus, totaling 22. Thus, the sample coincides with the population.

\section{Instrument}

For the construction of the instrument, an operational matrix was used, observing the objectives, variables, dimensions, indicators, items, and units of measurement (Mejía, 2005). We drew a Likert scale, composed of 25 items, grouped into four dimensions (extracted from the specific objectives): A (Environmental education), B (Technologies), C (Educational process), $\mathrm{D}$ (Awareness), and $\mathrm{E}$ (Practices).

\section{Validity of content}

To validate content on the scale, we relied on "expert judgment" and a "pilot test." In the judgment of experts, the corresponding validation questionnaires were carried out; reviewing the observations, we made some simple changes in the formulation of the items, which did not affect the content of the items. Finally, in the pilot test, when passing the scale obtained good results in understanding and coherence of items, so it was in the content validity scale.

\section{Construction validity (factorial analysis)}

The construction validity is referred to in the degree to which an instrument reflects the average construction, being elaborated operationally when the user wishes to make inferences about conduct or attributes that can group below the label of a particular constructor. It refers to whom so successfully an instrument represents and measures a theoretical concept (Bostwick \& Kyte, 2005). The factorial analysis is a statistical model that represents the relations between a set of variables, Fernando and Anguiano Carrasco (2010) with great success present that these relations can be explained from a series of unobservable (latent) variables 
Fernandez, Camargo, \& Nascimento. Technologies and environmental education: A beneficial relationship.

denominated factors, the number of factors being substantially lower than the variables. That is to say, the factorial analysis has as objectives the description of the relations of a series of variables, thanks to the formation of a smaller number of other common variables the first, mathematically defined (factors). The technique of factor analysis that we have applied in our research follows the following steps:

\section{Study of the correlation matrix}

It is necessary to study the correlation matrix to verify if our data are adequate to perform a Factor Analysis. This matrix must have a certain structure. To prove this, if Kaiser-Meyer-Olkin was used for the sample adequacy (KMO coefficient), in our case the value is 0.704 ; following Kaiser (1974), the value is acceptable, so we continue with the analysis.

\section{Extraction of factors}

Once it has been decided that the factorial analysis can give good results, the factors are extracted. For it, the Statistical Package for the Social Sciences (SPSS) provides different methods that differ in the interactive algorithm that the extractions use. SPSS brings by default the Principal Components method that starts with the totality of the commonality (whose value is one) in the common factors and, therefore, the final value of the commonality at the end of the interactive process is an indicator of the quality of the extraction in the sense that the variables with low values of final communality are poorly explained by the model. In good extraction, these values should be high in all variables. The resulting commonality table shows us only that there is an item with value .473, and the rest has a value greater than .500; we say nonetheless that this does not delete this item.

Table 1. Communality of variables.

Communalities

\begin{tabular}{|l|l|l|}
\hline A1.- Environmental education is important in the current context. & Initial & Extraction \\
\hline A2.- Knowledge about environmental problems is relevant in the teaching-learning process. & 1.000 & .886 \\
A3.- Environmental education triggers environmental preservation. & .889 \\
A4.- It is important to be up-to-date about the current environmental problems. & 1.000 & .915 \\
A5.- Environmental education helps on the environmental problems solution. & .762 \\
B6.- The usage of technology favors the awareness of environmental problems. & 1.000 & .856 \\
B7.- The usage of technology triggers the teaching-learning process. & 1.000 & .809 \\
B8.- It is important to use technology in the learning-teaching context. & 1.000 & .844 \\
B9.-The usage of technological resources instigates awareness of the environmental & 1.000 & .808 \\
problems. & .753 \\
B10.- The School favors the usage of technological resources in the process knowing the & 1.000 & .861 \\
environmental problems. & 1.000 & .718 \\
C11.- There is a relation between technology and environmental education. & .789 \\
C12.- The development of the Ambiental educational project favors the process of & 1.000 & \\
environmental awareness. & & \\
C13.- The usage of the internet develops the knowing process related to environmental & 1.000 & .923 \\
education. & & \\
C14.- Blogs and the educational platform are technological resources used in the process of & 1.000 & .746 \\
environmental awareness. & &
\end{tabular}


Fernandez, Camargo, \& Nascimento. Technologies and environmental education: A beneficial relationship.

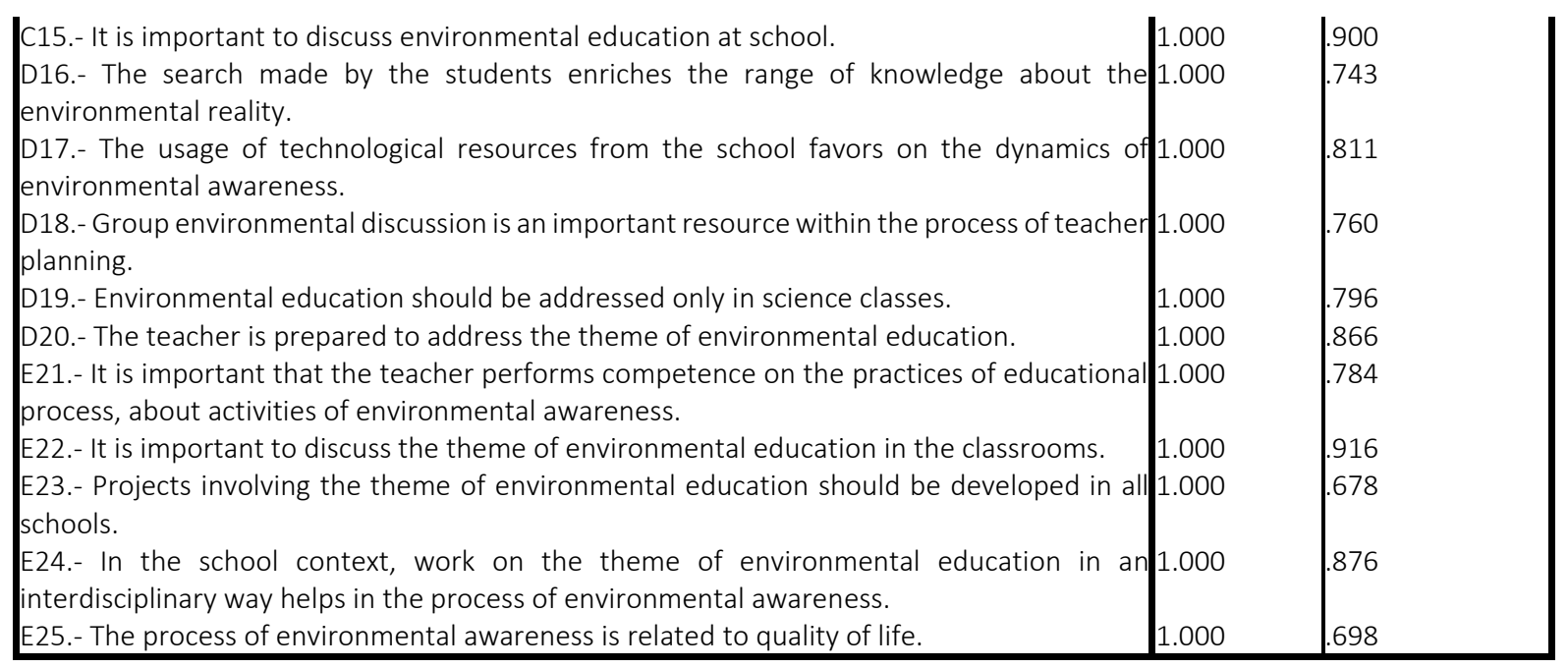

Extraction Method: Principal Component Analysis.

Source: Own elaboration.

The best represented items are: A3 (.915), C13 (.923), and C15 (.900):

A3. - Environmental education triggers the preservation of the environment.

C13.-The usage of the internet develops the knowledge process related to environmental education.

C15.- It is important to discuss environmental education at school.

The worst represented item is: E23 (.678):

E23.- Projects involving the theme of environmental education should be developed in all schools.

\section{Factor rotation}

The solution obtained in the processes of factor extraction is not the only one and, in addition, the structure of the problem does not change if we subject these factors to orthogonal rotations (rotations of the axes in which the angle is conserved). Therefore, the solution obtained may not be optimal. To perform rotations, there are several methods that follow the optimality criterion. One of them is the Varimax Rotation that optimizes the factorial loads in order to obtain the most extreme loads possible in the factors (high and low). There are rules for knowing the most appropriate number of factors to keep, for example, what is known as the Kaiser criterion (1958), which indicates that the main components whose own values are greater than unity must be conserved, although the most used is to observe the percentage of total variation explained by each component factor, and when it reaches a percentage accumulated considered high, in our case the first 7 factors, which explain $81.539 \%$ of the accumulated variation.

Table 2. Initial eigenvalues. 


\begin{tabular}{|l|l|l|l|l|l|}
\hline \multirow{2}{*}{ Component } & \multicolumn{3}{|l|}{ Autovalues initials } & \multicolumn{2}{l|}{} \\
\cline { 2 - 5 } & Total & \% of variation & \% accumulated & Total & \% accumulated \\
\hline 1 & 6.662 & 26.649 & 26.649 & 6.662 & 26.649 \\
2 & 4.037 & 16.147 & 42.796 & 4.037 & 42.796 \\
3 & 2.766 & 11.064 & 53.860 & 2.766 & 53.860 \\
4 & 2.535 & 10.139 & 63.999 & 2.535 & 63.999 \\
5 & 1.834 & 7.336 & 71.335 & 1.834 & 71.335 \\
6 & 1.419 & 5.674 & 77.009 & 1.419 & 77.009 \\
7 & 1.133 & 4.531 & 81.539 & 1.133 & 81.539 \\
8 & 987 & 3.946 & 85.486 & & \\
9 & .827 & 3.307 & 88.793 & & \\
10 & .623 & 2.493 & 91.286 & & \\
11 & .596 & 2.382 & 93.668 & & \\
\hline
\end{tabular}

Source: Own elaboration.

\section{Studies of factorial scores}

The factorial scores, that is, the value obtained by each individual of the sample in each factor, are estimated by different methods since it is not possible to obtain them exactly. By calculating the component matrix, we finally get 12 factors.

\section{Table 3. Component matrix.}

\begin{tabular}{|c|c|c|c|c|c|c|c|}
\hline & 1 & 2 & 3 & 4 & 5 & 6 & 7 \\
\hline $\begin{array}{l}\text { A1.- Environmental education is } \\
\text { important in the current context. } \\
\text { A2.- The knowledge about } \\
\text { environmental problems is } \\
\text { relevant in the teaching-learning } \\
\text { process. } \\
\text { A3.- Environmental education } \\
\text { triggers environmental } \\
\text { preservation. } \\
\text { A4.- It is important to be up-to- } \\
\text { date about the current } \\
\text { environmental problems. } \\
\text { A5.- Environmental education } \\
\text { helps on the environmental } \\
\text { problems solution. } \\
\text { B6.- The usage of technology } \\
\text { favors the awareness of } \\
\text { environmental problems. } \\
\text { B7.- The usage of technology } \\
\text { triggers the teaching-learning } \\
\text { process. } \\
\text { B8.- It is important to use } \\
\text { technology in the learning- } \\
\text { teaching context. } \\
\text { B9.- The usage of technological } \\
\text { resources instigate } \\
\text { awareness of environmental } \\
\text { problems. }\end{array}$ & $\begin{array}{l}.274 \\
.685 \\
.424 \\
.610 \\
.604 \\
.570 \\
.457 \\
.519 \\
.776 \\
.579\end{array}$ & $\begin{array}{l}.347 \\
-.129\end{array}$ & $\begin{array}{l}-.025 \\
-.071\end{array}$ & $\begin{array}{l}629 \\
-319\end{array}$ & $\begin{array}{l}.286 \\
-.428\end{array}$ & $\begin{array}{l}.298 \\
.065 \\
.287 \\
-.057\end{array}$ & $\begin{array}{l}.459 \\
.328\end{array}$ \\
\hline
\end{tabular}


Fernandez, Camargo, \& Nascimento. Technologies and environmental education: A beneficial relationship.
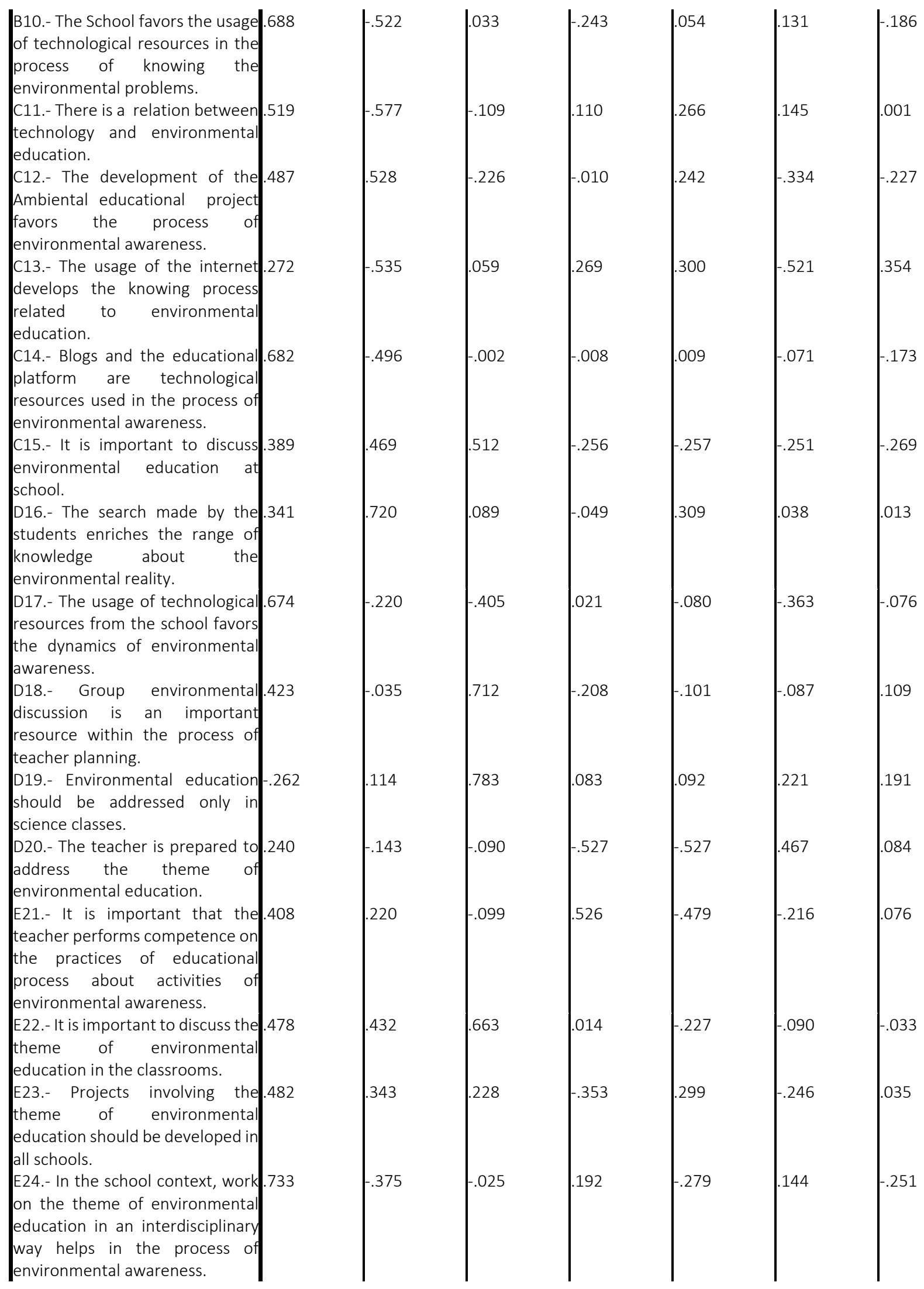
Fernandez, Camargo, \& Nascimento. Technologies and environmental education: A beneficial relationship.

\begin{tabular}{|l|l|l|l|l|l|l|l|l|}
$\begin{array}{l}\text { E25.- The process of } \\
\text { environmental awareness is } \\
\text { related to quality of life. }\end{array}$ & &. .181 & .382 & .376 & .472 & .231 & 5 \\
\hline
\end{tabular}

Extraction method: Main component analyses; 7 components extracted.

Source: Own elaboration.

Table 4. Analysis of explained and accumulated variation, as well as determination of factors and distribution of items taking into account the higher level of saturation by factors.

\begin{tabular}{|c|c|c|}
\hline Factor & Denomination & Items integrated in each factor of the questionnaire. \\
\hline \multirow[t]{5}{*}{1} & $\begin{array}{l}\text { A. ENVIRONMENTAL } \\
\text { EDUCATION }\end{array}$ & $\begin{array}{l}\text { A2.- Knowledge about environmental problems is relevant in the teaching- } \\
\text { learning process. } \\
\text { A4.- It is important to be up-to-date about the current environmental } \\
\text { problems. } \\
\text { A5.- Environmental education helps on the environmental problems solution. }\end{array}$ \\
\hline & B. TECHNOLOGY & $\begin{array}{l}\text { B6.- The usage of technology favors the awareness of environmental } \\
\text { problems. } \\
\text { B7.- The usage of technology triggers the teaching-learning process. } \\
\text { B8.- It is important to use technology in the learning-teaching context. } \\
\text { B9.- The usage of technological recourses instigates the awareness of the } \\
\text { environmental problems. } \\
\text { B10.- The School favors the usage of technological resources in the process of } \\
\text { knowing the environmental problems. }\end{array}$ \\
\hline & C. EDUCATIONAL PROCESS & $\begin{array}{l}\text { C11.- There is a relation between technology and environmental education. } \\
\text { C14.- Blogs and the educational platform are technological resources used in } \\
\text { the process of environmental awareness. }\end{array}$ \\
\hline & D. AWARENESS & $\begin{array}{l}\text { D17.- The usage of technological resources from the school favors on the } \\
\text { dynamics of environmental awareness. }\end{array}$ \\
\hline & E. PRACTICES & $\begin{array}{l}\text { E23.- Projects involving the theme of environmental education should be } \\
\text { developed in all schools. } \\
\text { E24.- In the school context, work on the theme of environmental education in } \\
\text { a interdisciplinary way helps in the process of environmental awareness. }\end{array}$ \\
\hline II & $\begin{array}{l}\text { C.- EDUCATIONAL PROCESS } \\
\text { D.- AWARENESS }\end{array}$ & $\begin{array}{l}\text { C12 } \\
\text { D16 }\end{array}$ \\
\hline III & $\begin{array}{l}\text { C.- EDUCATIONAL PROCESS } \\
\text { D.- AWARENESS } \\
\text { E.- PRACTICES }\end{array}$ & $\begin{array}{l}\text { C15 } \\
\text { D18, D19 } \\
\text { E22 }\end{array}$ \\
\hline IV & $\begin{array}{l}\text { A.-ENVIRONMENTAL } \\
\text { EDUCATION } \\
\text { E.- PRACTICES }\end{array}$ & $\begin{array}{l}\mathrm{A} 1, \mathrm{A3} \\
\mathrm{E} 21\end{array}$ \\
\hline $\mathrm{V}$ & E.- PRACTICES & E35 \\
\hline $\mathrm{VI}$ & D.- AWARENESS & $\mathrm{D} 20$ \\
\hline VII & C.- EDUCATIONAL PROCESS & C13 \\
\hline
\end{tabular}

Source: Own elaboration. 
Fernandez, Camargo, \& Nascimento. Technologies and environmental education: A beneficial relationship.

\section{Reliability}

As a general criterion, George and Mallery (2006) suggest the following recommendations to evaluate Cronbach's alpha coefficients: - alpha coefficient> .9 is excellent - alpha coefficient $>.8$ is good - alpha coefficient $>.7$ is acceptable - alpha coefficient $>.6$ is questionable - Coefficient alpha> .5 is poor. The Cronbach alpha coefficient of the Likert scale shows a high internal consistency of the set of these 25 variables and presents a value of $\alpha=.864$, which is a good value. According to the exploratory factorial analysis, it was decided to calculate in the first of the factors resulting to the alpha coefficient, to know the degree of internal consistency that presents, we removed the rest of the factor when having less than four items. The first factor consists of 13 relative variables, the remainder of which is .980 , which is excellent. The original school of 25 items gave us an alpha of .864, so we achieved a reduction of 12 items, with greater reliability, so we can conclude that our scale is validated in its construction.

\section{Descriptive analysis}

We will carry out the analysis of the most significant data offered by the Likert scale according to the dimensions of research.

\section{A. Environmental Education}

The descriptive analysis of this dimension gives us some information to highlight. In this way, the teachers interviewed think that environmental education is important in the current context, which stimulates the preservation of the environment, think that it is important to keep informed about current environmental problems and, for the most part, think that environmental education helps in solving environmental problems.

\section{B. Technology}

The teachers interviewed strongly agree that the use of technology favors knowledge about environmental problems, the use of technological resources stimulates awareness of environmental problems, that there is a relationship between technology and environmental education, as well as that the internet or technologies develop knowledge about environmental education.

\section{Educational Process}

In the descriptive analysis of these dimensions, we are told that teachers agree that the use of technological resources favors the dynamics of environmental awareness, as well as that it is important to discuss environmental education in the school. 
Fernandez, Camargo, \& Nascimento. Technologies and environmental education: A beneficial relationship.

\section{Awareness}

The teachers agree that the teacher is prepared to work on the theme of environmental education, and they do not agree that environmental education should be addressed only in science classes.

\section{E. Practices}

Finally, in this dimension, teachers are very much in agreement that it is important to discuss the theme of environmental education in the classroom, as well as to develop projects on the subject and carry out an interdisciplinary work on environmental education.

\section{Results and Discussions}

The results show that in Table 1, in the face of the Environmental Education dimension, the teachers mostly agree that environmental education stimulates the preservation of the environment, since it points out a totality of results 1.000 and extraction of .915. These data point to a good performance related to the choice of teachers, emphasizing A3.- Environmental education stimulates the preservation of the environment.

Referring to the Technology dimension in Table 1, most teachers agree that internet usage develops the knowledge process related to environmental education demonstrated in the result of commonality of 1.000 and extraction of .923, these results emphasize C13.- Internet use develops the knowledge process related to environmental education. It is noteworthy that in the Educational Process dimension in Table 1, teachers mostly agree that it is important to discuss environmental education in school, being represented by the result of commonality of data in 1.000 and extraction of .900, emphasizing the response of C15.- It is important to discuss environmental education at school. Regarding the Awareness process in Table 1, the teachers chose to highlight the use of the technological resource in the awareness process, resulting in a community of 1.000 and an extraction of .811, proving the answer of the D17.The use of technological resources of the school favors the dynamics of environmental awareness.

It is observed that referring to the practical dimension in Table 1, the teachers recognize that it is important to discuss the theme of environmental education in the classroom, resulting in commonality of 1.000 and extraction .916 in response to E22.- It is important to discuss environmental education in the classroom. In addition to agreeing in its majority that in the context, working on the theme of environmental education in an interdisciplinary way helps in the process of environmental awareness, the result is exposed by the commonality of 1.000 and extraction .876, proving E24. - In the school context, working on the theme of environmental education in an interdisciplinary way helps in the process of environmental awareness. In this way, the factorial analysis was done to validate the scale, because we not only wanted to do the scale to investigate, but to make a scale validated in its construction in a scientific way, so that it is a validated instrument for the scientific community. The original 
Fernandez, Camargo, \& Nascimento. Technologies and environmental education: A beneficial relationship.

scale has 25 items, and we were able to validate it with the factorial analysis and reduce it to 13 items with the highest reliability.

\section{Final Considerations}

We aimed in this article to address the question: Do teachers use and recognize technology as a partner in the process of environmental awareness? We sought to analyze the usage of technologies in the process of environmental awareness by the teachers of a Municipal School of Elementary Education of Alagoinha-Paraíba, as well as verifying the use of educational technologies in the process of environmental awareness. We wanted to understand the challenges faced by teachers in the process of using technology in environmental education, identify the activities developed by teachers involving technology and environmental education, in addition to perceiving the educational practices of teachers. The factorial analysis was developed for a greater reliability and forming a scientific character in the investigation. The data show that, unilaterally, teachers are attentive to issues related to the environment and the use of technology in this favor in the awareness process. Thus, when verifying the use of educational technologies in the process of environmental awareness, the great majority of participants agree that the use of the internet develops the knowledge process related to environmental education, being representative in the best items represented in the research, Table $1 \mathrm{C} 13, .923$. Consequently, in order to understand the challenges faced by teachers in the process of using technology in the field of environmental education, it was clear that item E23.- Projects involving environmental education should be developed in all schools, presents a challenge that starts from the lack of structure of some schools to develop this ability, to perceive the schools located in the rural area of the municipality.

By identifying the activities developed by teachers involving technology and environmental education, one can notice the predominance of the use of the blog, platform, and internet as technological resources within the process of environmental awareness. Teachers believe that there is a representative relationship between technology and environmental education. Hence, when perceiving the educational practices of teachers within the scope proposed by the research, one can notice that the use of projects and the accomplishment of interdisciplinary work on environmental education are important resources used in this dynamic of the classroom. Therefore, in response to the research problem: Do teachers use and recognize technology as a partner in the process of environmental awareness? It is noticed that teachers in their totality appreciate this theme, believing that technology and environmental education are in fact partners in the process of awareness, and that the school in question is inserted in this context to use the technology for this purpose. Finally, we noticed the teachers' concern about a topic of extreme relevance, environmental education and technology in the process of environmental awareness, in addition to the educational and methodological practices of the classroom, the teachers demonstrated a new look at the challenges, but also the strength in building care with the environment, which will bring an improved quality of life for all. Facing this challenge, teacher and student are the main agents. 
Fernandez, Camargo, \& Nascimento. Technologies and environmental education: A beneficial relationship.

\section{References}

Alkimin, G. D., Matos, J. P., Queiroz, T. V., \& Dornfeld, C. B. (2019). A educação ambiental escolar sob a perspectiva dos professores do Ensino Médio (Illha Solteira, SP). Revista Brasileira Do Ensino Médio, 2, 68-83. Disponível em: http://phprbraem.com.br/ojs/index.php/RBRAEM/article/view/18

Belloni, M. L. (2001). Educação à Distância. Campinas: Ed. Autores Associados.

Bisquera, R. (1993). Introducción conceptual al análisis multivariable. Un enfoque informático con los paquetes SPSS-X, BMDP, LISREL y SPAD. Barcelona: PPU.

Bostwick, G. J., \& Kyte, N. S. (2005). Measurement. In R. M. Grinnell \& Y. A. Unrau (Eds.), Social work research and evaluation: Quantitative and qualitative approaches. New York: Oxford University Press.

Boutelier, S. (2019). Limiting Learning Environments through Domestication. Journal of Culture and Values in Education, 2(1), 45-55. Retrieved from http://cultureandvalues.org/index.php/JCV/article/view/29

Cabero, A. J., \& Cejudo, C. L. (2006). Dominios tecnológicos de las tics por los estudiantes. Sevilla: Maqueta.

Collesanti, M. T., \& Rodrigues, G. S. S. (2008). Educação ambiental e as novas tecnologias de informação e comunicação. Revista Sociedade e Natureza, Uberlândia, 20(1), 51-66.

Constituição (1988). Constituição da República Federativa do Brasil, 1988. São Paulo: Editora Revista dos Tribunais.

Dias, G. F. (2001). A situação da educação ambiental no Brasil é fractal. In Brasil: Panorama da educação ambiental no ensino fundamental (p. 71-75). Brasília: Ministério da Educação.

Dias, G. F. (2004). Educação ambiental: Princípios e práticas. São Paulo: Gaia.

Ferrando, P. J., \& Anguiano, C. (2010). El análisis factorial como técnica de investigación en psicología. Papeles del Psicólogo, 31(1), 18-33.

George, D., \& Mallery, P. (2006). SPSS for Windows step by step: A simple guide and reference, 11.0 update. Boston: Allyn \& Bacon.

Gil, A. C. (2008). Métodos e técnicas de pesquisa social. São Paulo: Editora Atlas. 
Fernandez, Camargo, \& Nascimento. Technologies and environmental education: A beneficial relationship.

Hernández Fernández, A., \& De Barros, C. (2018). Metodología científica en humanidades. Jáen: Masquelibros.

Hernández Fernández, A., \& De Barros, C. (2016). Neurociência y tecnología en la inclusión educativa. Granada: Gami.

Kaiser, H. F. (1974). An index of factorial simplicity. Psychometrika, 39, 31-36.

Lafer, S. \& Tarman, B. (2019). Editorial 2019: (2)1, Special Issue. Journal of Culture and Values in Education, 2(1), i-v. Retrieved from http://cultureandvalues.org/index.php/JCV/article/view/34

Leff, E. (2002). Saber ambiental. Petrópolis: Vozes.

Maciel, J. L., Wachholz, C. B., Alminhana, C. O., Bitar, P. G., \& Muhle, R. P. (2019). Metodologias de uma educação ambiental inclusiva. Revista EGP. Retrieved from https://www2.portoalegre.rs.gov.br/sma/revista_EGP/Metodologia_Jaqueline_outros. pdf

Marques, R. N., \& Pastre, I. A. (2014). Relevância da química para uma sociedade sustentável. In O. M. Mascarenhas, K. Schlünzen, \& E. Moriya (Eds.), Coleção temas de formação: Química (Tomo II). São Paulo: Cultura Acadêmica.

Mejía, E. (2005). Metodología de la investigación científica. Lima: Universidad Nacional Mayor San Marcos.

Mendonça, F. (2002). Geografia socioambiental. In S. Kozel \& F. Mendonça (Eds.), Elementos de epistemologia da geografia. Paraná: UFPR.

Passarelli, B. (1993). Hipermídia na aprendizagem. Construção de um protótipo Interativo: a escravidão no Brasil. Tese (Doutorado em Ciências da Comunicação) - Departamento de Cinema, Rádio e Televisão da Escola de Comunicação e Artes, São Paulo: Universidade de São Paulo.

Pérez Ferra, M. (2009). La Europa del conocimiento, un referente axiológico para la universidad. In A. Medina, M. L. Sevillano, \& S. Torre (Eds.), Una universalidad para el siglo XXI. Espacio Europeo de Enseñanza Superior. Madrid: Universitas.

Pimenta, S. G. (1995). O estágio na formação de professores: Unidade teoria e prática? São Paulo: Cortez.

Sato, M. (2004). Educação ambiental. São Paulo: Rima. 
Fernandez, Camargo, \& Nascimento. Technologies and environmental education: A beneficial relationship.

UNESCO/PNUMA (2005). Década das Nações Unidas da Educação para um Desenvolvimento Sustentável, 2005-2014: Documento final do esquema Internacional de implementação. Brasília: UNESCO, 2005.

Valiandes, S. \& Tarman, B. (2011). Differentiated Teaching and Constructive Learning Approach by The Implementation of ICT in Mixed Ability Classrooms, Ahi Evran University Journal of Education Faculty, (KEFAD) 12(1), 169-184. 